\title{
Community-Based Mental Health Services in India: Current Status and Roadmap for the Future
}

\author{
Внебольничные службы психиатрической помощи в Индии: \\ текущее состояние и перспективы на будущее \\ DOI:10.17816/CP92
}

\section{Short Communication}

\section{Gagan Hans, Pratap Sharan}

Department of Psychiatry, All India Institute of Medical

Sciences, New Delhi, India

The article can be used under the CC BY-NC-ND 4.0 license

(c) Authors, 2021

\author{
Гаган Ганс, Пратап Шаран \\ Кафедра психиатрии, Всеиндийский институт \\ медицинских наук, Нью-Дели, Индия
}

Лицензия CC BY-NC-ND 4.0

(с) Коллектив авторов, 2021

\begin{abstract}
An estimated 197.3 million people have mental disorders in India, and majority of the population have either no or limited access to mental health services. Thus, the country has a huge burden of mental disorders, and there is a significant treatment gap. Public mental health measures have become a developmental priority so that sustainable gains may be made in this regard. The National Mental Health Program (NMHP) was launched in 1982 as a major step forward for mental health services in India, but it has only been able to partially achieve the desired mental health outcomes. Despite efforts to energize and scale up the program from time to time, progress with development of community-based mental health services and achievement of the desired outcomes in India has been slow. Public health measures, along with integration of mental health services in primary healthcare systems, offer the most sustainable and effective model given the limited mental health resources. The main barriers to this integration include already overburdened primary health centres (PHCs), which face the following challenges: limited staff; multiple tasks; a high patient load; multiple, concurrent programs; lack of training, supervision, and referral services; and nonavailability of psychotropic medications in the primary healthcare system. Thus, there is an urgent need for a fresh look at implementation of the NMHP, with a focus on achieving sustainable improvements in a timely manner.
\end{abstract}

\section{АНнОтАцИя}

По оценкам, в Индии 197,3 миллиона человек страдают психическими расстройствами, при этом большинство населения страны или вовсе не имеет возможности обратиться к службам психиатрической помощи, либо его доступ к ним ограничен. Таким образом, в стране прослеживается колоссальное бремя психических заболеваний при наличии существенной разницы между общим числом случаев возникновения рассматриваемых расстройств и количеством людей, получающих необходимое лечение. Меры профилактики психических заболеваний среди широких масс населения стали приоритетным направлением развития, ввиду чего в данной области можно ожидать долгосрочных успехов. В 1982 году была запущена Национальная программа психического здоровья (НППЗ) - важный шаг вперед в области развития служб психиатрической помощи Индии, который, однако, лишь отчасти смог достичь желаемых результатов в соответствующей области. Несмотря на все усилия по ускорению и оперативному расширению программы, прогресс в развитии внебольничных служб психиатрической помощи в Индии оказался недостаточным, а желаемые результаты не были достигнуты. Меры общественного здравоохранения, наряду с внедрением служб психиатрической помощи в систему 
первичной медико-санитарной помощи, предлагают наиболее устойчивую и эффективную модель с учетом ограниченных ресурсов специализированной психиатрической службы. Основным препятствием на пути такого внедрения является перегруженность центров первичной медико-санитарной помощи (ПМСП) и следующие проблемы, с которыми сталкиваются данные центры: ограниченное число персонала, чрезмерно широкий спектр задач, большое количество пациентов, единовременное проведение ряда различных программ, отсутствие профессионально подготовленных медицинских специалистов, надзорных и справочных служб и нехватка психотропных препаратов в системе первичной медико-санитарной помощи. Таким образом, существует острая необходимость в новом подходе к реализации НППЗ с фокусировкой на как можно более быстрое улучшение ситуации.

Keywords: community psychiatry; India; low- and middle-income countries (LMICS); public health; mental health services Ключевые слова: внебольничная психиатрия; Индия; страны с низким и средним уровнем дохода (СНСД); здравоохранение; службы психиатрической помощи

\section{INTRODUCTION}

Estimates made by the World Health Organization (WHO) suggest that mental and behavioral disorders account for around $12 \%$ of the global burden of disorders. ${ }^{1}$ It has been suggested that this may be an underestimation, considering the interconnectedness between mental illness and other socioeconomic conditions, especially in low- and middle-income countries (LMICs), which account for almost three quarters of the global burden of mental and behavioral disorders. ${ }^{2,3}$ An estimated 197.3 million people have mental disorders in India. ${ }^{4}$ Additionally, there is a significant treatment gap present in both developed and developing countries, with the vast majority of patients in LMICs lacking any access to treatment facilities for mental and behavioral disorders. ${ }^{2}$ Thus, public mental health measures have become increasingly important and should be a development priority, especially in LMICs, including India. ${ }^{5}$ Progress in this regard can be assessed according to the following criteria: presence of an official mental health policy; programs or plans for mental health; budgetary allocations; a dedicated mental health workforce; availability of essential psychotropic medications in primary care; increased treatment coverage; reduced suicide rates; and protection of the human rights of those who are mentally ill. ${ }^{3}$

\section{HISTORICAL PERSPECTIVES OF COMMUNITY MENTAL HEALTH IN INDIA}

Historically, in India, psychiatric patients have been cared for by family members in the community, in the absence of formal community psychiatric services. Community psychiatry barely existed in British India. The first psychiatric outpatient service, the precursor to present- day general hospital psychiatric units (GHPUs), was set up at the R.G. Kar Medical College, Calcutta, in 1933, by Ghirindra Sekhar Bose. This was followed by similar setups in Bombay (1938) and Patna (1939). However, for both mental health and general healthcare, many people did not have access to Western medical institutions and relied either on the traditional sector or Western-trained private practitioners. $^{6}$

The spread of community services can be traced back to the early 1950s in India. While there was a drive for deinstitutionalization in the Western world (based on the principle that humans have the right to be cared for in the community), institutionalization was not a major issue in India as there were few psychiatric beds available in hospitals. ${ }^{7}$ Thus, an important difference between the West and India, regarding development of community services, was that in India, this approach was supported primarily to make up for inadequate hospital-based services, rather than out of concern for human rights per se.

One of the earliest experimentations in community care (in 1952, before the advent of formal services) involved making provision for family members to stay with patients in tents on hospital premises during treatment, due to a shortage of available beds for admission to mental hospitals (an initiative instigated by Dr Vidya Sagar in Amritsar). ${ }^{7}$ In later decades, many new initiatives were introduced, which laid the foundations for community psychiatry in India. In 1964, a weekly community mental health service was started as part of the Comprehensive Rural Health Services Project (CRHSP), in Ballabgarh, by the All-India Institute of Medical Sciences (AlIMS), New Delhi. This was followed 
by establishment of two important community mental health services in the late seventies. WHO funded the project at Raipur Rani in Haryana under the aegis of the Postgraduate Institute of Medical Education and Research (PGIMER), Chandigarh. Further community mental health services were introduced in Sakalwada, Karnataka, under the aegis of the National Institute of Mental Health and Neurosciences (NIMHANS), Bangalore. ${ }^{7}$ These programs were the forerunners of the National Mental Health Program (NMHP) in India, which now includes community clinics in primary health centres (PHCs), supported by mental health professionals at district level, training of medical and multipurpose health workers, school mental health initiatives, home-based follow-up services by nurses and organization of psychiatric 'camps'.

\section{NATIONAL MENTAL HEALTH PROGRAM (NMHP)}

The National Mental Health Program (NMHP) was launched in 1982 as a major step forward for mental health services in India. It had three key objectives, including ensuring the availability and accessibility of a minimum level of mental healthcare for all, encouraging the application of mental health knowledge in general healthcare and promotion of community participation in the development of mental health services. Despite this being a ground-breaking initiative, the initial phases of implementation of the program were marred with difficulties. Various factors contributed to initial shortcomings like unrealistic targets; inadequate staff resources; inefficient administration; failure to develop indicators for addressing objectives; an inadequate emphasis on creating awareness among users; uncoordinated, fragmented efforts by various stakeholders; and inadequate budgetary support.7 Notwithstanding these flaws, one of the important achievements of the program during its first decade was recognition of a district-based model for provision of mental health services, with satellite primary health centres (PHCs) providing mental health services (based in the Bellary district in Karnataka state). ${ }^{8}$ This district model was subsequently expanded to cover four districts. The program was re-strategized in 2003 to include two schemes, namely 'Modernization of State Mental Hospitals' and 'Up-gradation of Psychiatric Wings of Medical Colleges/General Hospitals', to act as hubs, supporting mental health services in the community. The manpower development scheme (aimed at achieving mental health human-resource sufficiency) became part of the program in 2009. Under the first scheme, 15 existing mental hospitals/institutes/medical colleges were upgraded to start/strengthen courses in psychiatry, clinical psychology, psychiatric social work, and psychiatric nursing. Under the second scheme, 39 departments in 15 government medical colleges/government mental hospitals were given support to start/increase their intake of students for postgraduate (PG) courses in mental health. ${ }^{9}$

\section{DISTRICT MENTAL HEALTH PROGRAM (DMHP)}

The District Mental Health Program (DMHP) forms the core of the mental health services available at community level. The DMHP was launched as an extension of the NMHP in 1996, building on the success of the Bellary model in Karnataka, based on the realization that mental health services should primarily be dispensed through existing primary health facilities as creation of a parallel infrastructure for mental health was not immediately feasible, considering the prevailing (severe) limitations of mental health infrastructure and manpower. Thus, existing staff in these primary health centres (PHCs), like doctors and paramedical workers, were trained to provide mental health services. The National Institute of Mental Health and Neurosciences (NIMHANS), Bengaluru, provides medical officers with three months' training to equip them with the skills and knowledge necessary to treat psychiatric disorders at the primary level. ${ }^{10}$ There is also provision for referral services so that patients suffering from severe mental disorders can be directed to district hospitals. ${ }^{7}$ Table 1 lists the components of the DMHP. 9

In the period up to 2002, the DMHP was gradually extended to 25 districts across 20 Indian states. ${ }^{11}$ As of now, 241 districts (out of 718 districts in India) ${ }^{9}$ are covered under the scheme, and it is proposed that the DMHP be expanded to all districts in a phased manner. The population of various districts in India is highly variable, with a range from 0.008 million (in the least populated) to 11 million (in the most populated). ${ }^{12}$ The average population of districts in India in 2019 was 1.86 million (as per the Indian census). ${ }^{13}$ The National Mental Health Survey (NMHS) 2015-16 found the overall weighted prevalence for any mental morbidity in India to be $13.7 \%$ over a lifetime (then averaging 10.6\%) and that (at the time of the survey) there was a large treatment gap. ${ }^{14}$ This translates into very high numbers of individuals requiring 


\begin{tabular}{|l|l|}
\hline \multicolumn{2}{|l|}{ District Mental Health Program: } \\
\hline Service provision: provision of mental health outpatient and inpatient mental health services, with a 10-bed inpatient facility \\
\hline $\begin{array}{l}\text { Outreach } \\
\text { component }\end{array}$ & $\begin{array}{l}\text { 1.Satellite clinics: four satellite clinics per month at community health centres (CHCs)/ primary health centres } \\
\text { (PHCs) by the DMHP team } \\
\text { 2.Targeted interventions } \\
\text { 3.Life-skills education and counselling in schools } \\
\text { 4.College counselling services } \\
\text { 5.Workplace stress management } \\
\text { 6.Suicide prevention services }\end{array}$ \\
\hline Sensitization and training of health personnel (at district and subdistrict level) \\
\hline $\begin{array}{l}\text { Awareness camps to promote awareness of mental illnesses and related stigma, through involvement of local Panchayati Raj } \\
\text { Institutions (PRIs), faith healers, teachers, leaders, etc. }\end{array}$ \\
\hline $\begin{array}{l}\text { Community } \\
\text { participation }\end{array}$ & $\begin{array}{l}\text { 1.Links with self-help groups, family and caregiver groups, and nongovernmental organizations (NGOs) } \\
\text { working in the field of mental health } \\
\text { 2.Sensitization of enforcement officials regarding legal provisions for effective implementation of the Mental } \\
\text { Health Act }\end{array}$ \\
\hline
\end{tabular}

psychiatric services in these districts, which might be difficult to achieve even with universal coverage under the NMHP across all districts in India. Additionally, most of the population may have to bear the cost of out-ofpocket payments for mental health services as DMHP services with limited manpower may struggle to meet the mental health requirements of these populations, especially in overpopulated districts. Table 2 lists the manpower allocation for the DMHP. ${ }^{9}$

\section{NATIONAL MENTAL HEALTH POLICY}

A robust and comprehensive mental health policy is important to drive the growth of mental health services and systems. ${ }^{15}$ The National Mental Health Program (1982) and the Mental Health Act (1987) provided the implicit policy directions for community and institutional mental healthcare in India until recently. India's Mental Health Policy group was formed in May 2011. The National Mental Health Policy of India, entitled 'New Pathways, New Hope', was published by the Ministry of Health and Family Welfare, Government of India, in October 2014. ${ }^{16}$ The policy is inclusive in nature and incorporates an integrated, participatory, rights- and evidence-based approach, encompassing both medical and nonmedical aspects of mental health. The strategic areas identified for action are as follows: effective
Table 2. Manpower for the DMHP

\begin{tabular}{|l|l|l|}
\hline S.No. & Manpower (on a contractual basis) & $\begin{array}{l}\text { Number of } \\
\text { positions }\end{array}$ \\
\hline 1 & Psychiatrist & 1 \\
\hline 2 & Clinical Psychologist & 1 \\
\hline 3 & Psychiatric Nurse & 1 \\
\hline 4 & Psychiatric Social Worker & 1 \\
\hline 5 & Community Nurse & 1 \\
\hline 6 & Monitoring and Evaluation Officer & 1 \\
\hline 7 & Case Registry Assistant & 1 \\
\hline 8 & Ward Assistant/Orderly & 1 \\
\hline
\end{tabular}

governance and accountability; promotion of mental health; prevention of mental disorders and suicide; universal access to mental health services; enhanced availability of human resources for mental health; community participation; and research, monitoring and evaluation. It stresses delivery of mental health services within the existing healthcare system, using the primary healthcare approach, based on principles of universal access, equitable distribution, community participation, 
intersectoral coordination and use of appropriate technology. It also recognizes that these services should be comprehensive and should address the needs of persons with mental illness, their care providers and healthcare professionals.

\section{LEGISLATION}

Dedicated mental health legislation legally reinforces the goals of mental health policies and plans. ${ }^{17}$ Legislation is also important to prevent abuse and violation of the rights of patients with mental illness. As early mental health legislation was primarily drafted to safeguard the public from dangerous patients (by isolating such patients), the welfare of the patients themselves was always a secondary consideration. As a paradigm shift has occurred globally, towards a more rights-based approach for persons with a disability, including a mental disability (e.g., UNCRPD, 2006), ${ }^{18}$ the same principle is reflected in mental health legislation (i.e., the Mental Healthcare Act) (MHCA 2017), which superseded the Mental Health Act (MHA 1987). The new act is progressive and rights-based, but it mainly focuses on the rights of persons with mental illness during treatment in hospital, with limited discussion of the continuity of treatment in the community and the role of the family and community in management of individuals with mental illnesses. ${ }^{19}$

The MHCA 2017 has been criticized for failing to address Indian cultural sensitivities related to the involvement of families in treatment decisions. ${ }^{19}$ Families are a key resource for management in Indian society due to the cultural tradition of interdependence, and treatment teams also depend heavily on the active involvement of family members.

Mental health legislation must engage and work in tandem with legislation for people with disabilities, e.g., the Rights of Persons with Disabilities Act , 201620 and the National Mental Health Policy of India (2014). ${ }^{16}$ The Rights of Persons with Disabilities Act, 2016 includes mental illnesses, and it stresses full and effective participation and inclusion in society, nondiscrimination, accessibility, equality of opportunity and protection of the rights of individuals with disabilities. ${ }^{20}$ In LMICs (including India) where most people live in poor socioeconomic conditions, greater benefits and welfare measures like job preservation and housing schemes for patients with mental illness are needed.

\section{OTHER APPROACHES TO COMMUNITY MENTAL HEALTH IN INDIA}

Other significant approaches to community mental health in India include the camp approach, school mental health, NGO initiatives, media-based interventions, and telephone helplines.

There has been a long tradition of the camp approach for people living in remote areas with limited access to health services. The duration of these camps can vary, but most usually remain for a day in areas accessible by car or several days in places with limited access by road. The camp approach has been used to treat a range of mental health conditions (including addictions) and has also been utilized in times of natural disasters. ${ }^{7}$

Initiatives in school mental health have included a lifeskills education program for children and adolescents, with sensitization training for schoolteachers, focused on mental health problems prevalent in children and adolescents.

Nongovernmental organizations (NGOs) have been engaged in delivering mental health services with innovative models, to address the needs of local populations. There is also provision within the National Mental Health Program (NMHP) for state governments to execute activities relating to mental health in partnership with nongovernment organizations/agencies. ${ }^{9}$

\section{IMPACT OF COMMUNITY MENTAL HEALTH SERVICES}

The availability of studies considering long-term trends in prevalence rates of various psychiatric disorders in the Indian population is limited. These studies provide indirect and limited information about the performance of various mental health initiatives which have been implemented in the Indian population over previous decades. Early epidemiological studies in India reported variable prevalence rates for psychiatric conditions, thus impacting on planning, funding, and delivery of mental healthcare facilities. ${ }^{21}$

The National Mental Health Survey (NMHS) 2015-16 suggested that the overall weighted prevalence for any mental morbidity in India was $13.7 \%$ over a lifetime and $10.6 \%$ at the time of the survey. ${ }^{14}$ It also found a very high treatment gap of between $70 \%$ and $92 \%$ for different disorders, including $85 \%$ for common mental disorders, $73.6 \%$ for severe mental disorders and $75.5 \%$ for psychosis, among others. ${ }^{14}$ There have been suggestions 
about an increase in the crude prevalence and disabilityadjusted life-years (DALY) rate for depressive disorders, anxiety disorders, bipolar disorders and schizophrenia in India between 1990 and 2017, and a doubling of the proportional contribution of mental disorders to the total disease burden in India in the same period. ${ }^{4}$

Thus, despite the initiatives implemented to improve mental health services in India, minimal improvements have been seen at ground level. The factors contributing to this are the high treatment gap, poor implementation of mental health services, gender differentials in treatment and poor evidence-based treatments. ${ }^{22-26}$

\section{ROADMAP FOR THE FUTURE}

\section{Budgetary Considerations}

One of the primary reasons for the initial shortcomings following launch of the National Mental Health Program in 1982 was the shortage of allocated funds. Lack of a designated budget for mental health within a nation's health budget is a major impediment to service development. ${ }^{27}$ Another major difficulty which has been seen in India is underutilization of allocated funds 28 because of multiple factors, ranging from difficulty in employing mental health manpower to an inability to execute infrastructure projects in a time-limited manner. 'Redtapism' and lack of a coordinating nodal agency can also be a major hurdle in the timely execution of projects.

Funds allocated to the NMHP have decreased significantly in recent years, and this is a matter of concern. The Union Budget of India 2021-22 set a corpus sum of 712.69 billion Indian Rupees (INR) for the health budget, including 5.97 billion INR for mental health. Only 7 percent of the allocated amount for mental health has been earmarked for the NMHP. ${ }^{29}$ By way of comparison, the budget allocation for the NMHP in 2010 was $0.44 \%$ of the total budget allocated to the Ministry of Health and Family Welfare, but this was reduced to $0.06 \%$ in 2020 . Moreover, another major cause for concern is that major cuts have been made in the revised NMHP budget estimates in recent years. For example, in 2018-19, the allocated amount of 500 million INR was slashed to 55 million INR, and in 2019-20, the allocated amount of 400 million INR was slashed to 50 million INR. ${ }^{30}$ Thus, underfunding continues to be a major barrier, contributing to slow gains under the NMHP.
Hence, ring-fencing allocated funds to be used exclusively for mental health services, along with a nodal agency to ensure this, may go a long way towards ensuring proper utilization of funds allocated for mental health. ${ }^{31}$

\section{Mental Health Service Delivery}

The recommendation to deinstitutionalize mental health and to adopt a primary health model for service delivery has been longstanding. ${ }^{32}$ While institutionalization has been seen as a major challenge in the West since adoption of a rights-based approach to mental health, this has not been the case in India, along with other LMICs. ${ }^{7}$ Direct adoption of the same approach in LMICs (including India) may not necessarily have similar desirable effects on overall service provision in these countries as they already have a dearth of mental health resources. However, existing mental hospitals and institutions can serve as referral centres in the management of patients with severe mental illnesses, especially where there is insufficient social support and for medicolegal cases, ${ }^{33}$ while the transition to predominantly community-based services is being planned and implemented. The current policy of strengthening and upgrading existing mental hospitals to 'Centres of Excellence', along with provisions for strengthening of the mental health training being incorporated into the National Mental Health Program, will provide the essential building blocks for successful community-based services as envisioned. ${ }^{9}$ However, periodic reappraisal of the goals set, achievement thus far and course corrections is essential, and the mechanisms ensuring this must be built into the program to prevent skewed development. In recent years, the overall scope of mental health services and a significant reduction in stigma have been achieved, but this comes with the caveat that these services are essentially concentrated around urban and semiurban areas.

\section{Mental Health Workforce}

Factors contributing to the shortage of mental health professionals in LMICs (including India) are urban concentration, a preference for private practice and the brain drain. ${ }^{1,5}$ There is an acute shortage of mental health professionals in India, with two mental health workers and 0.3 psychiatrists per 100,000 population, which is a major limiting factor when it comes to planning mental health services for communities. ${ }^{34}$ Retaining mental health 
professionals is an even greater challenge, along with ensuring their equitable distribution. Minimizing the brain drain and retaining professionals in the public sector must be afforded a high priority by means of financial incentives, favourable working conditions, and provisions for career advancement. ${ }^{35}$ At the same time, efforts should be made to ensure that enhanced training capacities are adequately utilized by ensuring equal professional opportunities for trained personnel. It is envisaged that, in the District Mental Health Program, existing manpower will be trained in PHCs (like doctors and paramedical staff) and equipped with the skills and knowledge necessary to provide mental health services. Nonspecialist health workers contribute to service delivery and play an important role in detection, diagnosis, treatment, and prevention of common and severe mental disorders as part of a complex steppedcare approach. There should be better provision for their in-service training to enable them to deliver effective services to the general population..$^{35}$

Another important approach to improving service provision for the general population is to improve psychiatry education and training at the level of undergraduate medical courses. ${ }^{31}$ The ability to independently diagnose and treat mental disorders and make appropriate referral decisions will improve service provision on a much wider scale, with visible improvements.

\section{Mobilization of Community Resource}

In many LMICs, including India, faith healers, religious leaders and practitioners of alternative systems of medicine are often the first point of contact for patients with psychiatric disorders, rather than mental health services. ${ }^{36}$ Efforts must be made to educate and sensitize this subgroup of the population about the importance of seeking a professional diagnosis and undergoing appropriate treatment (with regular followup), supported by better delivery of mental health services in the community. Some services can be sought as time-limited interventions (like camp services), which can mobilize large numbers of people in a limited time, in remote areas. Community campaigns to increase awareness about psychiatric illnesses and decrease the associated stigma should also be prioritized as stigma and discrimination against people with mental health problems are important barriers to identification and treatment of mental disorders. ${ }^{37}$ Family members are essentially the primary caregivers in most LMICs, including India, and can contribute to detection, treatment-seeking, and management of family members with mental disorders. ${ }^{35}$

\section{Integration with Primary Care}

Currently, integration of community mental health services with primary healthcare is the most viable method to provide mental health services in most LMICs, including India, but significant shortcomings still exist in terms of achieving this goal..$^{38}$ The main barriers to integration include the following: already overburdened PHCs with limited staff; multiple tasks; patient load; multiple concurrent programs; lack of training, supervision and referral services; and non-availability of psychotropic drugs in the primary healthcare system. ${ }^{32}$ In this context, alternative mechanisms for program delivery, like the National Health Mission (which subsumed the National Rural Health Mission and National Urban Health Mission in India), should be considered. It has also been suggested that mental healthcare should be integrated with better performing services for other chronic conditions or, alternatively, with other systems like social care or education. ${ }^{39}$

\section{Mental Health Research}

The WHO's Mental Health: Global Action Program envisages multidimensional research efforts in LMICs to improve the mental health situation. ${ }^{40}$ There is a wide gap between research efforts focused on developed countries and those focused on LMICs (in terms of mental health), and this divide has not decreased over time. ${ }^{41}$ Furthermore, research does not seem to have had an impact on the policy and practice of mental health due to a disconnect between researchers and communities. ${ }^{42}$ Attention needs to be focused on a systemic approach in order to debate the relevance of research questions, with the involvement of all stakeholders at appropriate levels (including policymakers, practitioners, advocacy groups and the community at large), and to generate resources and funds for this. ${ }^{42-44}$

\section{CONCLUSIONS}

Although progress has been slow in development of community-based mental health services and achievement of the desired outcomes in India, the importance of these cannot be understated. India has 
a huge burden of mental disorders and a significant treatment gap. 2,4 Public health measures, along with integration of mental health services in primary health systems, offer the most sustainable and effective model for LMICs with few resources, including India. Despite the National Mental Health Program having been in effect since 1982, it has only been able to partially achieve the desired mental health outcomes. ${ }^{8}$ It is important to continuously assess performance with independent audits and periodic reviews in order to identify problems at the earliest and initiate corrective measures..$^{45}$ Thus, there is an urgent need to take a fresh look at implementation of the program, with a focus on achieving sustainable improvements in a timely manner.

\section{Manuscript process:}

Submitted: 14.07.2021

Accepted: 03.09.2021

Published: 30.09 .2021

Funding: The research was carried out without additional funding.

Conflict of interests: The authors report no conflicts of interest.

Authors" contribution: G. Hans, P. Sharan Conceptualisation, Literature review, Article writing.

\section{Correspondence to:}

\section{Gagan Hans}

gaganhans23@gmail.com

\section{For citation:}

Hans G, Sharan P. Community-based mental health services in India: Current status and roadmap for the future. Consortium Psychiatricum. 2021;2(3):63-71. DOI:10.17816/CP92

\section{References}

1. WHO. The World health report: 2001 : Mental health : new understanding, new hope. Geneva: WHO; 2001. Accessed August 18, 2021. https://www.who.int/whr/2001/en/whr01_ en.pdf

2. WHO. mhGAP: Mental Health Gap Action Programme: scaling up care for mental, neurological and substance use disorders. Geneva: WHO; 2008. Accessed August 18, 2021. https://www.who. int/mental_health/mhgap_final_english.pdf
3. Lancet Global Mental Health Group: Chisholm D, Flisher AJ et al. Scale up services for mental disorders: a call for action. Lancet. 2007;370(9594):1241-1252. doi:10.1016/s0140-6736(07)61242-2

4. India State-Level Disease Burden Initiative Mental Disorders C. The burden of mental disorders across the states of India: the Global Burden of Disease Study 1990-2017. Lancet Psychiatry. 2020;7(2):148-161. doi:10.1016/S2215-0366(19)30475-4

5. Lund C, De Silva M, Plagerson S, et al. Poverty and mental disorders: breaking the cycle in low-income and middle-income countries. Lancet. 2011;378(9801):1502-1514. doi:10.1016/S01406736(11)60754-X

6. Nizamie SH, Goyal N. History of psychiatry in India. Indian J Psychiatry. 2010;52(Suppl 1):S7-S12. doi:10.4103/00195545.69195

7. Chadda RK. Six decades of community psychiatry in India. Int Psychiatry. 2012;9(2):45-47. PMC6735056

8. Murthy RS. Mental health initiatives in India (1947-2010). Natl Med J India. 2011;24(2):98-107.

9. National Mental Health Programme. Directorate General of Health Services, Ministry of Health and Family Welfare, Government of India. Accessed August 18, 2021. https://dghs.gov. in/content/1350_3_NationalMentalHealthProgramme.aspx

10. Singh OP. District Mental Health Program - Need to look into strategies in the era of Mental Health Care Act, 2017 and moving beyond Bellary Model. Indian J Psychiatry. 2018;60(2):163-164. doi:10.4103/psychiatry.IndianJPsychiatry_304_18

11. Goel DS. Why mental health services in low- and middle-income countries are under-resourced, underperforming: an indian perspective. Natl Med J India. 2011;24(2):94-97.

12. District Census 2011. Accessed August 18, 2021. https://www. census2011.co.in/district.php

13. Do India's newly added districts yield desired governance results? Accessed August 18, 2021. https://economictimes.indiatimes.com/ news/politics-and-nation/do-indias-newly-added districts yielddesired-governance-results/articleshow/70516246.cms?from=mdr

14. Gautham MS, Gururaj G, Varghese M, et al. The National Mental Health Survey of India (2016): Prevalence, socio-demographic correlates and treatment gap of mental morbidity. Int J Soc Psychiatry. 2020;66(4):361-372. doi:10.1177/0020764020907941

15. WHO. Improving health systems and services for mental health. Geneva: World Health Organization; 2009. Accessed August 18, 2021. https://apps.who.int/iris/bitstream/ handle/10665/44219/9789241598774_eng.pdf

16. New Pathways New Hope. National Mental Health Policy of India, Ministry of Health and Family Welfare, Government of India, 2014. Accessed August 18, 2021. http://nhm.gov.in/images/pdf/ National_Health_Mental_Policy.pdf

17. WHO. Mental health atlas 2011. Geneva: World Health Organisation; 2011. Accessed August 18, 2021. https://apps.who. int/iris/bitstream/handle/10665/119996/emropub_2013_ 1578.pdf

18. United Nations Convention on the rights of Persons with disabilities, 2006. Accessed August 18, 2021. https://www.un.org/ development/desa/disabilities/convention-on-the-rights-ofpersons-with-disabilities.html

19. Math SB, Basavaraju V, Harihara SN, et al. Mental Healthcare Act 2017 - Aspiration to action. Indian J Psychiatry. 2019;61(Suppl 4): S660-S666. doi:10.4103/psychiatry.IndianJPsychiatry_91_19

20. Rights of Persons with disabilities Act, 2016. Department of Empowerment of Persons with Disabilities (Divyangjan), Ministry of Social Justice and Empowerment, Government of India. 
Accessed August 18, 2021. http://disabilityaffairs.gov.in/content/ page/acts.php

21. Math SB, Chandrashekar CR, Bhugra D. Psychiatric epidemiology in India. Indian J Med Res. 2007;126(3):183-192. PMID: 18037711

22. Petersen I, Marais D, Abdulmalik J, et al. Strengthening mental health system governance in six low- and middle-income countries in Africa and South Asia: challenges, needs and potential strategies. Health Policy Plan. 2017;32(5):699-709. doi:10.1093/ heapol/czx014

23. Mugisha J, Abdulmalik J, Hanlon C, et al. Health systems context(s) for integrating mental health into primary health care in six Emerald countries: a situation analysis. Int J Ment Health Syst. 2017;11:7. doi:10.1186/s13033-016-0114-2

24. Shidhaye R, Raja A, Shrivastava S, et al. Challenges for Transformation: A Situational Analysis of Mental Health Care Services in Sehore District, Madhya Pradesh. Community Ment Health J. 2015;51(8):903-912. doi:10.1007/s10597-015-9893-1

25. Kaur R, Pathak RK. Treatment gap in mental health: reflections from policy and research. Econ Polit Wkly 2017;52:34-40.

26. Arvind BA, Gururaj G, Loganathan S, et al. Prevalence and socioeconomic impact of depressive disorders in India: multisite population-based cross-sectional study. BMJ Open. 2019;9(6):e027250. doi:10.1136/bmjopen-2018-027250

27. Jacob KS, Sharan P, Mirza I, et al. Mental health systems in countries: where are we now? Lancet. 2007;370(9592):1061-1077. doi:10.1016/S0140-6736(07)61241-0

28. Goel DS. The National Mental Health Program: Problems, perspectives, possibilities. In: Public mental health: An evolving field. Ministry of Health, Government of India; 2011.

29. India's budget for mental health leaves a lot to be desired. Only INR 400 million for National Mental Health Programme. Accessed August 18, 2021. https://mediaindia.eu/society/mental-healthbudget-2021/

30. Mental Health, not a priority, fiscally. Accessed August 18, 2021. https://www.ha-asia.com/mental-health-not-a-priority-fiscally/.

31. Sharan P, Sivakumar T. Roadmap for the Future: What is Needed in the Region? In: Trivedi J, Tripathi A, eds. Mental Health in South Asia: Ethics, Resources, Programs and Legislation. International Library of Ethics, Law, and the New Medicine. Springer, Dordrecht;2015;263-277. doi:10.1007/978-94-017-9017-8_15.

32. Saraceno B, van Ommeren M, Batniji R, et al. Barriers to improvement of mental health services in low-income and middleincome countries. Lancet. 2007;370(9593):1164-1174. doi:10.1016/ S0140-6736(07)61263-X
33. Wig N. Vision 2020: Roadmap for the future-II. Mainstreaming mental health. In: Mental Health: An Indian Perspective, 1946-2003. Directorate General of Health Services, Ministry of Health \& Family Welfare, Government of India;2004:341-343.

34. WHO. Mental Health Atlas 2017. Geneva: World Health Organization, 2017. Accessed August 18, 2021. https://www.who. int/publications/i/item/9789241514019

35. Kakuma R, Minas $\mathrm{H}$, van Ginneken $\mathrm{N}$, et al. Human resources for mental health care: current situation and strategies for action. Lancet. 2011;378(9803):1654-1663. doi:10.1016/S01406736(11)61093-3

36. Trivedi JK, Jilani AQ. Pathway of psychiatric care. Indian J Psychiatry. 2011;53(2):97-98. doi:10.4103/0019-5545.82530

37. Thornicroft G, Alem A, Antunes Dos Santos R, et al. WPA guidance on steps, obstacles and mistakes to avoid in the implementation of community mental health care. World Psychiatry. 2010;9(2):67-77. doi:10.1002/j.2051-5545.2010.tb00276.x

38. Jacob KS. Repackaging mental health programs in low- and middle-income countries. Indian J Psychiatry. 2011;53(3):195-198. doi:10.4103/0019-5545.86798

39. Eaton J, McCay L, Semrau M, et al. Scale up of services for mental health in low-income and middle-income countries. Lancet. 2011;378(9802):1592-1603. doi:10.1016/S0140-6736(11)60891-X

40. Saxena S, Sharan P, Saraceno B. Research for Change: the role of scientific journals publishing mental health research. World Psychiatry. 2004;3(2):66-72. PMC1414672

41. Saxena S, Paraje G, Sharan P, Karam G, Sadana R. The 10/90 divide in mental health research: trends over a 10-year period. $\mathrm{Br}$ J Psychiatry. 2006;188:81-82. doi:10.1192/bjp.bp.105.011221

42. Saxena S, Sharan P. Research for change: supporting mental health research in India. Natl Med J India. 2003;16(3):122-125.

43. Saxena S, Sharan P. Enhancing mental health research publication from low and middle-income countries. Indian J Psychiatry. 2004;46(1):72-78. PMC2912681

44. Sharan P, Gallo C, Gureje O, et al. Mental health research priorities in low- and middle-income countries of Africa, Asia, Latin America and the Caribbean. Br J Psychiatry. 2009;195(4):354-363. doi:10.1192/bjp.bp.108.050187

45. Goel D, Agarwal S, Ichhpujani R, Shrivastava S. Mental health 2003: The Indian scene. In: Mental health: An Indian perspective (19462003). Directorate General of Health Services, Ministry of Health and Family Welfare, Government of India/ Elsevier;2004:3-24. Accessed August 18, 2021. https://mhpolicy.files.wordpress. com/2011/05/mental-health-e-book_published10oct20041.pdf 